\title{
Implementasi kebijakan pengurangan penggunaan kantong plastik di Kota Denpasar
}

\author{
Yohanes Kopong Blolo*
}

Fakultas Ilmu Sosial dan Politik, Universitas Pendidikan Nasional Denpasar, Indonesia

\begin{abstract}
Abstrak Penelitian ini bertujuan untuk menganalisis kebijakan pemerintah dalam mengurangi penggunaan kantong plastik di Kota Denpasar. Penelitian ini dilakukan di Kota Denpasar karena adanya Peraturan Walikota Denpasar No. 36/2018. Metode penelitian yang digunakan adalah metode deskriptif kualitatif dengan pendekatan induktif. Pendekatan ini menganalisis kinerja kebijakan pengurangan penggunaan kantong plastik. Pemilihan informan menggunakan metode purposive sampling. Responden adalah petugas DLHK Kota Denpasar dan informan masyarakat. Teknik pengumpulan data dilakukan dengan wawancara kepada informan yang ditentukan berdasarkan kebutuhan penelitian ini. Dalam penelitian ini teknik analisis data yang digunakan adalah reduksi data, kemudian dilanjutkan dengan penyajian data dan penarikan kesimpulan. Hasil penelitian menemukan bahwa pelaksana mengingatkan dan membagikan tas ramah lingkungan. Telah terjadi komunikasi dan sosialisasi kebijakan regulasi. Komunikasi internal pelaksana sangat baik dalam mensosialisasikan kebijakan. Kelompok sasaran mendukung aturan tersebut, sehingga pelaksanaan kebijakan berjalan dengan lancar dan sesuai ekspektasi. Ruang politik dan ekonomi membantu melaksanakan kebijakan ini. Keamanan dan budaya Bali memfasilitasi implementasi kebijakan.
\end{abstract}

Kata kunci: kebijakan pemerintah; implementasi; kinerja; peraturan; tas ramah lingkungan

\begin{abstract}
This study aims to analyze government policies to reduce the use of plastic bags in Denpasar City. This research is in Denpasar City because of Denpasar Mayor Regulation No. 36/2018. The research method used is a qualitative descriptive method with an inductive approach. This approach analyzes the performance of policies to reduce the use of plastic bags. Selection of informants using a purposive sampling method. The respondents were Denpasar City DLHK officials and community informants. The data collection technique was carried out by interviewing the informants determined based on the needs of this study. In this study, the data analysis technique used was data reduction, then continued with the presentation of the data and drawing conclusions. The results of the research found that implementers reminded and distributed environmentally friendly bags. There has been communication and socialization of regulation policies. The implementor's internal communication is very good in disseminating policies. The target group supports the rule, so that policy implementation runs smoothly and meets expectations. Political and economic space helps implement these policies. Balinese security and culture facilitate policy implementation.
\end{abstract}

Keywords: government policy; implementation; performance; regulation; environmentally friendly bags

JEL Classification: $K_{32}, Q 53$

\footnotetext{
* Penulis koresponden

E-mail: yohanesadonara93@gmail.com
} 


\section{PENDAHULUAN}

Pertumbuhan penduduk di Indonesia selalu bertambah di setiap tahunnya baik itu di kota maupun di desa sekalipun. Jumlah total populasi sekitar 260 juta (dua ratus enam puluh juta) penduduk, Indonesia adalah negara berpenduduk terpadat nomor empat di dunia. Kebutuhan masyarakat kian bertambah dan beriringan akan bertambahnya volume sampah serta karakteristik sampah yang semakin beragam jenisnya.

Sampah menjadi salah satu persoalan yang sering jadi masalah yang harus diselesaikan oleh pihak yang terkait. Menurut Sucipto (2012), sampah merupakan bahan padat buangan dari kegiatan rumah tangga, pasar, perkantoran, rumah penginapan, hotel, rumah makan, industri, puingan bahan bangunan dan besi-besi tua bekas kendaraan bermotor. Sampah merupakan hasil sampingan dari aktivitas manusia yang sudah terpakai.

Berdasarkan definisi tersebut tentang sampah, sehingga sampah merupakan barang bekas pakai yang sudah tidak digunakan lagi baik itu sampah organik maupun sampah anorganik. Sampah organik adalah sampah yang masih bisa didaur ulang secara alami, sedangkan sampah anorganik adalah sampah yang tidak bisa didaur ulang secara alami. Persoalan sampah sering dikeluhkan di berbagai kota besar, karena memang menjadi akibat atau penyebab kesehatan lingkungan menjadi terganggu (Rochman dkk, 2015).

Permasalahan sampah menjadi serius untuk ditindaklanjuti demi keselamatan dan kesehatan lingkungan hidup. Penyelesaian persoalan sampah berbeda-beda sesuai jenis sampahnya. Sampah yang berjenis plastik akan lebih sulit diatasi dikarenakan sampah plastik tidak dapat didaur ulang secara alami. Sampah plastik sulit untuk didaur ulang karena terbuat dari penyulingan gas dan minyak bumi (sumber daya alam yang tidak dapat diperbaharui) sehingga membutuhkan ratusan tahun untuk terurai dengan sempurna (Jalil dkk, 2013).

Kendala utama mengganti penggunaan plastik adalah merubah kebiasaan menggunakan kantong plastik (Zhu, 2011). Merupakan tanggung jawab utama pemerintah untuk memberikan pemahaman yang masif, konsisten, dan tepat sasaran bagi para pedagang pasar. Denpasar yang sebagai ibu kota Provinsi Bali menjadi salah satu kota yang sedang mengalami persoalan sampah. Dalam sehari, Kota Denpasar menghasilkan 3.500 kubik atau 1.200 ton sampah perhari. Volume sampah ini sama dengan pengangkutan sebanyak 530 kali angkut ke TPA.

Pada tahun terakhir, sampah plastik juga menjadi permasalahan tersendiri. Pada tahun 2015, Indoensia menjadi negara terbesar pembuang sampah di Asia Tenggaran (Jambeck dkk, 2015). Data Dinas Lingkungan Hidup dan Kebersihan (DLHK) Kota Denpasar, menunjukan jumlah sampah plastik tiap harinya mencapai 16 persen dari total produksi sampahnya. Data terakhir menunjukan bahwa sampah plastik telah mencemari $30 \%$ biota laut, sedangkan kemasan plastik baru bisa hancur 30 tahun lamanya. Kerusakan lingkungan dan ekosistem dapat disebabkan oleh berbagai hal: penumpukan sampah dari pembuangan limbah yang bersumber dari industri dan rumah tangga (Yorenza dan Yusran, 2020). 
Peraturan pelaksanaan tentang larangan penggunaan kantong plastik belum efektif karena banyak pihak yang belum siap dengan kebijakan ini terutama masyarakat dan kurangnya sanksi. Kebijakan ini tidak terlalu berguna, seperti yang terjadi di beberapa kota di pulau Jawa dan Sumatera. Wacana pelarangan kantong plastik masih dalam tahap sosialisasi gerakan untuk lingkungan sehat tanpa plastik (Asmadianto dkk, 2020). Pemerintah memiliki kewajiban mengeluarkan kebijakan untuk publik atau aturan untuk menyelesaikan persoalan-persoalan yang terjadi pada lingkungan wilayahnya, demi tercapainya kenyamanan pada masyarakat banyak (Maruf, 2019).

Peraturan yang berfokus pada pelarangan penggunaan kantong plastik 'sekali pakai', memberlakukan pajak dan retribusi yang lebih tinggi kepada konsumen, secara signifikan mengurangi konsumsi kantong plastik (Adeyanju dkk, 2021). Berkaitan dengan peraturan yang dikeluarkan oleh Wali Kota Denpasar maka pemerintah memberikan larangan penyediaan kantong plastik di minimarket, supermarket, departement store, hypermarket ataupun grosir sehingga masyarakat yang berbelanja pada tempat-tempat yang disebutkan harus menyiapkan kantong sendiri ataupun keranjang sejenisnya untuk menyimpan barang belanjaannya. Kantong plastik yang dimaksudkan adalah kantong yang terbuat dari/atau mengandung bahan dasar plastik, lateks atau polyethylene, thermoplastik synthetic polymeric, atau bahan-bahan sejenis lainnya, dengan/atau tanpa pegangan tangan, yang digunakan sebaai media untuk mengangkat atau mengangkut barang.

Kebijakan yang dikeluarkan oleh pemerintah tentang pengurangan penggunaan kantong plastik ini juga menimbulkan berbagai macam persepsi masyarakat, hal demikian dikarenakan kebiasaan masyarakat yang sering sekali menggunakan kantong plastik untuk menyimpan sesuatu baik itu barang belanjaan dan atau barang bawaannya sendiri. Kebijakan ini berupaya merubah pola pikir dan gaya hidup maka dibutuhkan waktu yang cukup lama dan pengertian yang serius dari masyarakat umum khususnya di Kota Denpasar.

\section{METODE PENELITIAN}

Penelitian ini dilakukan di Kota Denpasar, tepatnya di dinas lingkungan hidup dan kebersihan. Dipilihnya kota denpasar sebagai lokasi penelitian karena peneliti hanya akan meneliti tentang Peraturan kebijakan Walikota Denpasar No 36 Tahun 2018 tentang Pengurangan Penggunaan Kantong Plastik di wilayah Kota Denpasar. Metode penelitian yang digunakan adalah metode deskriptif kualitatif dengan pendekatan induktif, dimana akan digambarkan bagaimana implementasi kebijakan pengurangan penggunaan kantong plastik hingga nantinya dapat diperoleh pernyataan secara menyeluruh.

Pemilihan informannya akan penulis lakukan dengan menggunakan purposive sampling dimana informan yang dipilih adalah pejabat/aparatur yang ada di DLHK Kota Denpasar dan informan dari masyarakat. Teknik pengumpulan data dilakukan dengan metode wawancara dengan informan yang telah ditentukan berdasarkan kebutuhan dari penelitian ini. Dalam penelitian ini teknik analisa data 
yang digunakan adalah dengan melakukan reduksi data, kemudian dilanjutkan penyajian data dan penarikan kesimpulan.

\section{HASIL DAN PEMBAHASAN}

Implementasi kebijakan pada dasarnya adalah suatu sikap atau tindakan agar kebijakan dapat mencapai tujuannya, dengan begitu proses mengimplementasikan kebijakan tentu ada beberapa faktor yang akan berpengaruh. Peraturan Walikota Denpasar Nomor 36 Tahun 2018 tentang Pengurangan Penggunaan Kantong Plastik, merupakan salah satu kebijakan yang telah diterbitkan untuk mengatasi persoalan sampah plastik.

Studi ini menggunakan pandangan Makmur dan Thahier (2016) tentang teori faktor-faktor yang berpengaruh dalam implementasi kebijakan Peraturan Walikota Denpasar No 36 Tahun 2018.

\section{Materi Kebijakan Publik}

Li dan Zhao (2017) menganalisis faktor-faktor yang dapat memengaruhi implementasi kebijakan regulasi kantong plastik. Lima faktor dampak diidentifikasi berdasarkan data statistik, yaitu lokasi geografis, minat industri yang dapat dicapai, biaya hidup, tingkat perkembangan ekonomi, dan tingkat pendidikan penduduk.

Penyusunan materi pada sebuah kebijakan yakni Peraturan Walikota Denpasar Nomor 36 Tahun 2018 tentang Pengurangan Penggunaan Kantong Plastik harus jelas dan mudah dimengerti oleh kelompok sasaran yakni masyarakat Kota Denpasar, sehingga masyarakat boleh melaksanakan intruksi kebijakan sesuai yang diharapkan. Hasil wawancara kepada Sekertaris Dinas Lingkungan Hidup dan Kebersihan menyatakan Peraturan Nomor 36 Tahun 2018 tentang Pengurangan Penggunaan Kantong Plastik ini dengan bahasa yang sangat sederhana dan tidak mengandung makna yang berganda sehingga cukup jelas dimengerti oleh masyarakat. Pernyataan juga diungkapkan oleh Staf Dinas Lingkungan Hidup dan Kebersihan, Bidang Pengelolaan Sampah menyatakan: 'pada saat kami turun untuk melakukan sosialisasi, masyarakat tidak merasa kesulitan dalam memahami peraturan tersebut". Dari hasil wawancara tersebut peneliti menyimpulakan bahwa materi Peraturan Walikota Denpasar Nomor 36 Tahun 2018 tentang Pengurangan Penggunaan Kantong Plastik ini cukup jelas dan dapat dimengerti oleh kelompok sasaran yakni masyarakat Kota Denpasar.

\section{Biaya Implementasi Kebijakan Publik}

Negara menggunakan kebijakan mengatur ukuran tebal plastik dan mengenakan retribusi/cukai melalui mekanisme pasar. Akan tetapi dalam pelaksanaannya sedikit berbeda-beda dipengaruhi oleh respon dari masyarakat (Yustiani dan Maryadi, 2019).

Anggaran merupakan sesuatu hal yang sangat penting terhadap pelaksanaan berbagai kegiatan atau pekerjaan, ketersediaan anggaran atau pembiayaan sebenarnya menjadi faktor pendukung dalam rangka usaha implementasi kebijakan publik, dalam hal ini biaya untuk mengimplementasikan Peraturan Walikota 
Denpasar Nomor 36 Tahun 2018. Sebagai hasil wawancara implementor kebijakan peraturan Walikota Denpasar No 36 Tahun 2018 tentang Pengurangan Penggunaan Kantong Plastik, staf bidang pengelolaan sampah di Dinas Lingkungan Hidup dan Kebersihan Kota Denpasar mengatakan bahwa: "dari kita dana kalo ga salah APBD nanti di konfirmasi lagi kesekertaris saya, dan ada CSR itu dari Bank BPD terus dari Astrea dan banyak lagi tpi coba nanti di jelaskan lebih lanjut ke pimpinan saya". Hasil wawancara denagn Sekretaris Dinas Lingkungan Hidup dan Kebersihan menyatakan:

"bantuan anggaran untuk mensosialisasikan perwali ini dan sekaligus membagikan kantong ramah lingkungan yakni bantuan dari CSR dan juga anggaran APBD. Dengan anggaran itu bisa cukup tapi ini persoalan dengan perilaku,karena merubah perilaku manusia itu tidak mudah membalikan telapak tangan, oleh sebab itu kalau sosialisasi dan sudah membagikan kantong ramah lingkungan juga kalau kedepannya masyarakat masih tetap tidak membawanya disaat belanja berarti kita tidak bisa memperkirakan anggaran lagi kedepan,tapi ya mudah-mudahan perilaku masyarakat bisa berubah karena persentasi penggunaan kantong plastik seakarang sudah menurun".

Berdasarkan pendapat informan diatas dapat disimpulakan bahwa dana untuk mengimplementasikan kebijakan peraturan Walikota No 36 Tahun 2018 tentang Pengurangan Penggunaan Kantong Plastik sudah mencukupi hanya saja kekuatiran dari Dinas Lingkungan Hidup dan Kebersihan sebagai implementor kebijakan bahwa kedepannya perilaku masyarakat kota denpasar tidak membawa lagi kantong ramah lingkungan atau dengan sengaja terus membuang kantong ramah lingkungan yang sudah dibagikan maka instansi terkait harus lagi mengingatkan dan dengan membagikan lagi kantong ramah lingkungan.

\section{Komunikasi Kebijakan Publik}

Kebijakan publik Peraturan Walikota Denpasar Nomor 36 Tahun 2018 tentang Pengurangan Penggunaan Kantong Plastik akan terimplementasi dengan baik jika melalui komunikasi dengan tercipta saling pengertian dalam kesepakatan, berarti memperkuat implementasi kebijakan publik tentang pengurangan penggunaan kantong plastik, sebaliknya jikaulah tidak terjadi saling pengertian dalam kesepakatan berarti melemahkan usaha implementasi kebijakan publik tentang pengurangan penggunaan kantong plastik. Hasil wawancara kepada Sekertaris Dinas Lingkungan Hidup dan Kebersihan menyatakan:

"sebelum peraturan ini ditetapkan kita sudah sosialisasi diawal, sosialisasi kita mengundang LSM, kita mengudang CSR, kita membuat satu event untuk sampah plastik, terus kita waktu HUT Kota Denpasar 2019 itu kita pengurangan sampah plastik itu dengan penyebaran tas-tas ramah lingkungan kita berikan, bertukar untuk yang mereka bawa kresek sebanyak 20 lembar, kalo yang bawa botol bekas kita tukar sama tabler. Itu dengan program kita terus sosialisasi terus dilokasi car fre day, kita aksi jalan kita menyampaikan kemasyarakat bahwa tidak lagi menggunakan kresek".

Hal senada juga disampaikan oleh Staf Dinas Lingkungan Hidup dan Kebersihan, bidang pengelolaan sampah menyatakan bahwa mereka selalu turun 
untuk melakukan sosialisasi kemasyarakat tentang pengurangan penggunaan kantong plastik ini, bahkan pimpinan sendiri kadang juga langsung turun kemasyarakat untuk melakukan sosialisasi.

Dari hasil wawancara tersebut peneliti menyimpulkan bahwa sudah ada komunikasi dan atau sosialisasi kebijakan peraturan Walikota Denpasar No 36 Tahun 2018 tentang Pengurangan Penggunaan Kantong Plastik di Kota Denpasar. Dalam melaksanakan sosialisasi kebijakan Peraturan Walikota Denpasar Nomor 36 Tahun 2018 tentang Pengurangan Penggunaan Kantong Plastik terdapat hambatan, seperti yang dijelaskan oleh Sekertaris Dinas Lingkungan Hidup dan Kebersihan menyatakan bahwa: "namanya suatu kegiatan untuk program itu ada sih hambatan dan kendala-kendala namun karena dikomunikasikan dari awal dengan baik itu maka hambatan apapun itu terselesaikan". Hal senada juga disampaikan oleh Staf Dinas Lingkungan Hidup dan Kebersihan menyatakan bahwa: "ada sih kendala namun kendala apapun itu harus mampu untuk tidak dijadikan sebagai penghambat dalam melakukan sosialisasi ke masyarakat".

Berdasarkan pendapat informan diatas dapat dikatakan bahwa tidak ada kendala yang serius dari Dinas Lingkungan Hidup dan Kebersihan Kota Denpasar dalam melakukan sosialisasi kebijakan peraturan Walikota Denpasar No 36 Tahun 2018 tentang Pengurangan Penggunaan Kantong Plastik. Komunikasi interen pelaksana kebijakan peraturan walikota denpasar nomor 36 tahun 2018 tentang pengurangan penggunaan kantong plastik ini juga menentukan bagaimana proses sosialisasi. Hasil wawancara kepada Sekertaris Dinas Lingkungan Hidup dan Kebersihan menyatakan: "komunikasi kami dalam proses pelaksanaan kebijakan ini cukup terbuka satu antara yang lain sehingga ketika ada perbedaan pendapatpun kita akan segera langsung mengkomunikasikannya secara baik agar kegiatan sosialisasi ini benar-benar berjalan sesuai yang kita rencanakan".

Hal senada juga disampaikan oleh staf bidang pengelolaan sampah di Dinas Lingkungan Hidup dan Kebersihan Kota Denpasar, mengatakan bahwa: "Komunikasi seperti biasa kami sebagai staf mendengar dari atasan kami baru kami tindak lanjuti apa yang diperintahkan oleh atasan kami”. Dari hasil wawancara diatas dapat dikatakan bahwa komunikasi dari pihak intern atau pihak implementor yakni Dinas Lingkungan Hidup dan Kebersihan Kota Denpasar dalam menjalankan kebijakan tersebut sangat baik dan sebagai kekuatan keberhasilan dalam mensosialisasikan kebijakan peraturan Walikota Denpasar No 36 Tahun 2018 tentang Pengurangan Penggunaan Kantong Plastik karena keterbukaan dalam memberikan intruksi dan komunikasi antar implementor.

\section{Implementor Kebijakan Publik}

Di dalam implementasi, perlu ada konsultasi terbatas saat merancang larangan, tidak hanya nasional. Pemberitahuan masih terbatas (kurang dari satu tahun) antara pengumuman larangan dan implementasi selanjutnya. Harus ada ketentuan untuk alternatif yang dapat digunakan kembali (Adam dkk, 2020). Implementor pada kesempatan ini adalah aparatur negara atau aparatur pemerintah Dinas Lingkungan Hidup dan Kebersihan Kota Denpasar yang diberikan tugas dan tanggungjawab dalam rangka mengimplementasikan kebijakan peraturan Walikota Denpasar 
Nomor 36 Tahun 2018 tentang Pengurangan Penggunaan Kantong Plastik kepada kelompok sasaran yakni masyarakat Kota Denpasar. Bagi implementator senantiasa dituntut kemampuan fisik dan kemampuan dibidang ilmu pengetahuan sehingga menguasai atau memahami materi dan tujuan kebijakan publik yang akan diimplementasikan dan pada akhirnya dapat memberikan hasil sesuai harapan sebelumnya. Hasil wawancara Sekertaris Dinas Lingkungan Hidup dan Kebersihan Kota Denpasar menyatakan:

"untuk melaksanakan atau tugas kami untuk menjalankan perwali ini adalah sesuatu hal yang tidak terlalu sulit untuk kami lakukan, yang dibutuhkan hanyalah semangat dan kami semua dengan semangat sekali untuk turun melakukan sosialisasi kemasyarakat dengan cara apapun itu seperti yang sudah kami sepakati bersama. Jumlah kami membagi 50 orang yang menyebar ke kecamatan untuk melakukan sosialisasi. Dan khusus untuk perwali ini kami lakukan dengan secara bersama dan tidak ada kekurangan tenaga".

Hal senada juga disampaikan oleh Staf Dinas Lingkungan Hidup dan Kebersihan Kota Denpasar, bidang pengelolaan sampah menyatakan bahwa mereka tidak merasa ada kesulitan dalam menjalankan sosialisasi perwali ini karena sederhana saja mereka menyampaikan perwali ini. Tidak perlu ada pelatihan untuk kami karena untuk melakukan sosialisasi tinggal saja membagi tugas dan mereka akan melakukan sesuai yang ditugaskan oleh masing-masing kami.

Dari hasil wawancara yang penulis dapat dari informan, bisa disimpulkan bahwa sumber daya manusia Dinas Lingkungan Hidup dan Kebersihan sebagai Implementor dalam hal melaksanakan kebijakan Peraturan Walikota Denpasar No 36 Tahun 2018 tentang Pengurangan Penggunaan Kantong Plastik sudah baik dan tidak mengalami kesulitan dalam mensosialisasikan kebijakan peraturan Walikota Denpasar No 36 Tahun 2018 tentang Pengurangan Penggunaan Kantong Plastik di Kota Denpasar.

\section{Kelompok Sasaran Kebijakan Publik}

Partisipasi publik dalam program penanganan sampah plastik sangat menentukan (Asmuni dkk, 2015). Anggota masyarakat Kota Denpasar merupakan kelompok sasaran dalam mengimplementasikan kebijakan Peraturan Walikota Denpasar Nomor 36 Tahun 2018 tentang Pengurangan Penggunaan Kantong plastik. Dukungan dari masyarakat Kota Denpasar sebagai kelompok sasaran dan kerja sama dengan para implementor kebijakan peraturan walikota nomor 36 tahun 2018 ini agar berjalan lancar sesuai dengan yang dikehendaki bersama. Hasil wawancara dengan Sekertaris Dinas Lingkungan Hidup dan Kebersihan Kota Denpasar menyatakan:

"masyarakat sangat mendukung dengan kebijakan peraturan wali kota denpasar tentang pengurangan penggunaan kantong plastik ini, dalam bentuk membawa tas sendiri dari rumahnya itu dukungan dari masyarakat coba sekarang ke pasar rakyat disini pasar rakyat di ubung itu sudah dominan membawa tas dari rumah ibu-ibu semua itu sudah dominan bawa tas dari rumah, pasar rakyat yang kita anggap segmen yang paling susah untuk berubah. Terus dukungan dari masyarakat 
buktinya dari pasar-pasar, tokoh-tokoh itu masyarakat juga itu mereka sudah tidak menyediakan berarti dukungannya sangat bagus itu. Sekolah-sekolah SD,SMP negeri 3 itu sama sekali tidak menyediakan pokoknya ada unsur plastiknya sampe tempat minum pun dia da jual air mineral dari plastik dia bawa galongan kalo ada murid yang mau beli pake galong lalu diisi ke tamlernya, kalo dari OPD-OPD dinas dinas itu setiap kali mereka rapat itu mereka tidak menyediakan snak yang ada unsur plastik sama air mineral juga tidak ada unsur plastik mereka pake glas".

Demikian juga yang dikemukakan oleh seorang masyarakat Kota Denpasar, beliau mengatakan: "Saya sepakat dengan aturan mengenai tentang pengurangan penggunaan kantong plastik,biar sampah plastik bisa berkurang karena selama ini sampah plastik memang paling banyak". Hal senada juga dikemukakan oleh masyarakat kota denpasar, Pak Budiono selaku komposting di Tempat Pembuangan Sampah Sementara di wilaya Sidakarya mengatakan bahwa: "Dengan peraturan yang dikeluarkan oleh Walikota Denpasar saya sangat sepakat dengan itu, karena dengan peraturan itu sampah plastik bisa berkurang karena memang penyumbang sampah paling banyak saat ini adalah sampah plastik".

Berdasarkan pendapat informan diatas, penulis dapat menyimpulkan bahwa kelompok sasaran dalam kebijakan peraturan Walikota Denpasar No 36 Tahun 2018 tentang Pengurangan Penggunaan Kantong Plastik di Kota Denpasar yakni masyarakat sangat mendukung dengan peraturan Walikota Denpasar No 36 Tahun 2018 tentang Pengurangan penggunaan Kantong Plastik, dengan begitu peraturan ini akan lebih mudah untuk sukses dan bisa berjalan dengan lancar karena kelompok sasaran kebijakan sudah terbuka dan mau melakukan apa yang diatur oleh Walikota Denpasar.

\section{Struktur Birokrasi}

Legislasi yang efektif bergantung pada penegakan yang konsisten dan mendidik kepada masyarakat untuk mencapai dukungan lingkungan (Nyathi dan Togo, 2020). Struktur birokrasi yang relatif stabil dan menciptakan suasana kepastian dari berbagai kondisi, merupakan suatu kondisi yang dapat memperlancar atau dengan kata lain memperkuat implementasi kebijakan publik. Apabila struktur birokrasi yang senantiasa mengalami fluktuasi atau selalu mengalami perubahan sehingga menciptakan ketidak stabilan semua aspek kehidupan dalam dunia kepublikan, hal ini berarti menjadi tantangan atau hambatan dalam rangka mengimplementasi kebijakan publik. Hasil wawancara dengan Sekertaris Dinas Lingkungan Hidup dan Kebersihan Kota Denpasar menyatakan: "tidak ada persoalan dalam struktur organisasi kami, kami sudah ada punya kewenangan masing-masing yang sudah jelas ada dan tidak ada tumpang tindih dalam melakukan koordinasi".

Hal senada juga disampaikan oleh staf bidang pengelolaan sampah di Dinas Lingkungan Hidup dan Kebersihan Kota Denpasar, mengatakan bahwa struktur organisasi normal apa adanya seperti biasa dari pimpinan melakukan perintah lalu mereka sebagai bawahan melaksanakan perintah dari atasan. Berdasarkan hasil wawancara diatas, penulis dapat menyimpulkan bahwa struktur Dinas Lingkungan 
Hidup dan Kebersihan dalam keadaan yang stabil sehingga koordinasi antar implementor berdasarkan tugasnya masing-masing sangat bagus, sehingga demikian kebijakan Peraturan Walikota Denpasar No 36 Tahun 2018 tentang Pengurangan Penggunaan Kantong Plastik di Kota Denpasar bisa disosialisasikan dengan baik dan lancar oleh Dinas Lingkungan Hidup dan Kebersihan Kota Denpasar dalam hal ini sebagai Implementor kebijakan Peraturan Walikota Denpasar No 36 Tahun 2018 Tentang Pengurangan Penggunaan Kantong Plastik.

\section{Kondisi Politik dan Ekonomi}

Suasana politik yang stabil sangat mendukung implementasi kebijakan publik serta memiliki peluang yang besar untuk keberhasilannya. Sebaliknya, jika kondisi politik menggambarkan kondisi yang tidak stabil atau kondisi fluktuasi juga sangat mempengaruhi implementasi kebijakan publik. Berdasarkan hasil wawancara Sekertaris Dinas Lingkungan Hidup dan Kebersihan Kota Denpasar menyatakan: "pimpinan kami beliau orang profesional, beliau tidak memikirkan politik apapun itu, beliau mengamankan amanat rakyat, beliau berbuat untuk rakyat tidak ada unsur politik yang beliau lakukan".

Hal senada juga disampaikan oleh staf bidang pengelolaan sampah di Dinas Lingkungan Hidup dan Kebersihan Kota Denpasar, mengatakan bahwa: "tidak mempengaruhi ini masalah lingkungan, yang justru dalam ruang politik sekalipun harus ikut terlibat dalam menjalankan peraturan ini untuk menjaga lingkungan kita kedepannya".

Berdasarkan pendapat informan diatas dapat disimpulkan bahwa keadaan politik tidak mempengaruhi kebijakan peraturan Walikota Denpasar No 36 Tahun 2018 tentang Pengurangan Penggunaan Kantong Plastik di Kota Denpasar, karena justru ruang politik juga ikut membantu dalam hal melaksanakan kebijakan peraturan Walikota Denpasar tersebut.

Sama halnya dengan kondisi ekonomi, jika ekonomi kondisinya semakin stabil, maka dapat memperkuat dan mendukung keberhasilan implementasi kebijakan publik, tetapi jika kondisi ekonomi tidak stabil, maka kemungkinan implementasi kebijakan publik akan mengalami hambatan dan kegagalan. Hasil wawancara dengan Sekertaris Dinas Lingkungan Hidup dan Kebersihan Kota Denpasar menyatakan: "kondisi ekonomi tidak ada pengaruhnya dengan kebijakan perwali ini, sekarang hanya perilaku yang dirubah saja tidak ada kaitan dengan ekonomi, kalaupun ada kaitan berarti perilaku manusia itu yang belum berubah".

Hal senada juga disampaikan oleh staf bidang pengelolaan sampah di Dinas Lingkungan Hidup Kota Denpasar, mengatakan bahwa: "tidak mempengaruhi justru dengan menggunakan tas ramah lingkungan kan tidak sekali pake dipake berualang kali jadi mala menguntungkan jika dilihat dari ekonomi keuangan masyarakat pembeli ataupun sebaliknya masyarakat yang berdagang".

Berdasarkan hasil wawancara yang diperoleh dari informan, penulis menyimpulkan bahwa ekonomi saat ini tidak mempengaruhi kebijakan peraturan Walikota Denpasar No 36 Tahun 2018 tentang Pengurangan Penggunaan Kantong Plastik karena justru mala dengan kebijakan ini perekenomian dalam perdagangan 
menjadi lebih baik dan malah justru ada penambahan keuntungan dari kebijakan peraturan Walikota Denpasar No 36 Tahun 2018 tentang Pengurangan Penggunaan Kantong Plastik ini.

8. Kondisi Keamanan dan Budaya

Beberapa faktor yang menyebabkan konsumen mengabaikan kampanye 'diet kantong plastik', antara lain alasan fungsional, sosial, budaya, dan struktural (Wijaya dkk, 2020). Kondisi keamanan sesungguhnya dapat menjadi faktor pendorong keberhasilan implementasi kebijakan publik, tetapi jika sebaliknya kondisi kemanan tidak kondusif, maka kemungkinannya implementasi kebijakan publik akan mengalami kegagalan. Hasil wawancara dengan Sekertaris Dinas Lingkungan Hidup dan Kebersihan Kota Denpasar menyatakan: "kondisi kemanan sangat aman, dan memang tidak ada masalah di bali, kondisi bali selalu aman damai".

Hal senada juga disampaikan oleh Staf Dinas Lingkungan Hidup dan Kebersihan Kota Denpasar menyatakan: "kondisi bali saat ini aman, tidak ada pengaruh keamanan dengan kebijakan pengurangan penggunaan kantong plastik ini". Berdasarkan hasil wawancara yang diperoleh dari informan, dapat disimpulkan bahwa kondisi bali saat ini aman tidak ada kesulitan apapun terhadap kondisi keamanan di Bali untuk menjalankan kebijakan Peraturan Walikota Denpasar No 36 Tahun 2018 tentang Pengurangan Penggunaan Kantong Plastik.

Materi kebijakan publik senantiasa tidak sejalan bertentangan dengan nilai-nilai budaya pada kelompok masyarakat, dapat kita katakan akan menghambat proses implementasi kebijakan publik tersebut. Dengan demikian bahwa sasaran yang diharapkan kemungkinan tidak terwujud dengan baik. Hasil wawancara dengan Sekertaris Dinas Lingkungan Hidup dan Kebersihan Kota Denpasar menyatakan:

"Perwali Nomor 36 Tahun 2018 tentang pengurangan penggunaan kantong plastik ini tidak bertentangan dengan budaya bali, karena di Bali itu kan ada 3 hubungan manusia dengan manusia, manusia dengan Tuhan, manusia dengan alam. Kalau sekarang kita menggunakan kantong plastik berarti kita tidak ada hubungan dengan alam karena plastik bisa merusakan kestabilan alam".

Hal senada juga dikemukakan oleh staf bidang pengelolaan sampah di Dinas Lingkungan Hidup Kota Denpasar, mengatakan bahwa: "tidak bertentangan karena budaya orang Bali selalu mencintai dan menghormati lingkungan". Berdasarkan hasil wawancara yang diperoleh dari informan, penulis menyimpulkan bahwa kebijakan peraturan Walikota Denpasar No 36 Tahun 2018 tentang Pengurangan Penggunaan Kantong Plastik di Kota Denpasar tidak bertentang dengan budaya Bali, karena di Bali menjalankan tiga tradisi keyakinan tentang hubungan manusia dengan Tuhan, hubungan manusia dengan manusia, hubungan manusia dengan alam. Dengan demikian budaya Bali justru malah mendukung kebijakan peraturan Walikota Denpasar No 36 Tahun 2018 tentang Pengurangan Penggunaan Kantong plastik. Kebijakan ini masuk dalam sebuah keyakinan bahwa hubungan manusia dengan alam. Suatu lingkungan yang bersih dan terus menjaga kelestarian alam bali. 


\section{KESIMPULAN}

Dinas Lingkungan Hidup dan Kebersihan Kota Denpasar sebagai implementor kebijakan bahwa harus mengingatkan dan dengan membagikan lagi kantong ramah lingkungan. Sudah ada komunikasi dan atau sosialisasi kebijakan peraturan walikota. Komunikasi dari pihak intern atau pihak implementor yakni dalam menjalankan kebijakan tersebut sangat baik dan sebagai kekuatan keberhasilan dalam mensosialisasikan kebijakan.

Kelompok sasaran dalam kebijakan, dalam studi ini masyarakat, sangat mendukung dengan peraturan walikota. Peraturan ini lebih mudah untuk sukses dan bisa berjalan dengan lancar karena kelompok sasaran kebijakan sudah terbuka dan mau melakukan apa yang diatur oleh Walikota Denpasar. Struktur Dinas Lingkungan Hidup dan Kebersihan dalam keadaan yang stabil sehingga koordinasi antar implementor berdasarkan tugasnya masing-masing sangat bagus. Peraturan Walikota disosialisasikan dengan baik dan lancar oleh Dinas Lingkungan Hidup dan Kebersihan.

Ruang politik ikut membantu dalam hal melaksanakan kebijakan peraturan tersebut. Ekonomi saat ini tidak mempengaruhi kebijakan peraturan, justru pengurangan Penggunaan Kantong Plastik karena justru mala dengan kebijakan ini perekenomian dalam perdagangan menjadi lebih baik dan malah justru ada penambahan keuntungan dari kebijakan peraturan Walikota Denpasar No 36 Tahun 2018 tentang Pengurangan Penggunaan Kantong Plastik ini.

Kondisi Bali saat ini aman tidak ada kesulitan apapun terhadap kondisi keamanan di Bali untuk menjalankan kebijakan. Kebijakan sesuai budaya Bali, tiga tradisi keyakinan tentang hubungan manusia dengan Tuhan, hubungan manusia dengan manusia, hubungan manusia dengan alam. Untuk merubah perilaku kebiasaan masyarakat Kota Denpasar sangat susah sehingga butuh kesabaran implementor.

\section{UCAPAN TERIMAKASIH}

Terimakasih disampaikan kepada universitas pendidikan nasional yang telah mentransfer ilmu pengetahuan untuk penelitian dan publikasi artikel ini. Penulis menyampaikan terimkasih kepada reviewer artikel ini yang telah memberikan masukan yang konstruktif untuk meningkatkan kualitas substansi ilmiah dari artikel ini.

\section{DAFTAR PUSTAKA}

(1) Adeyanju, G. C., Augustine, T. A., Volkmann, S., Oyebamiji, U. A., Ran, S., Osobajo, O. A., dan, Otitoju, A. (2021). Efectiveness of intervention on behaviour change against use of non-biodegradable plastic bags: a systematic review. Discover Sustainability, 2(13), 1-15. doi: https://doi.org/10.1007/s43621-021-00015-0 
(2) Asmadianto, A., Arfah, K. A. ., \& Krismiyati, K. (2020). Policy implication of prohibition of using plastic bags at shopping centres. International Journal of Social Sciences, 3(1), 116-121. doi: https://dx.doi.org/10.31295/ijss.v3n1.198

(3) Asmuni, S., Hussin, B. H., Khalili, J. M., Zain, Z. M. (2015). Public Participation and Effectiveness of the No Plastic Bag Day Program in Malaysia. Procedia - Social and Behavioral Sciences, 168, 328-340. doi: https://doi.org/10.1016/i.sbspro.2014.10.238

(4) Jalil, M. A., Mian, M. N. Rahman, M. K. (2013). Using plastic bags and its damaging impact on environment and agriculture: An alternative proposal. International Journal of Learning and Development, 3(4), 1-14. doi: https://doi.org/10.5296/ijld.v3i4.4137

(5) Jambeck, J. R., Geyer, R., Wilcox, C., Siegler, T. R., Perryman, M., Andrady, A., Narayan, R., \& Law, K. L. (2015). Plastic waste inputs from land into the ocean, Science, 347(6223), 768-771. doi: https://doi.org/10.1126/science.1260352

(6) Makmur dan Thahier, R. (2016). Konseptual dan Kontekstual Administrasi dan Organisasi Terhadap Kebijakan Publik. Bandung. Refika Aditama.

(7) Maruf, M. (2019). Law and policy in addressing marine plastic litter: Indonesia response and recent development. Journal of Indonesian Legal Studies, 4(2), 167-188. doi: https://doi.org/10.15294/jils.v4i2.34757

(8) Nyathi, B. dan Togo, C. A. (2020). Overview of legal and policy framework approaches for plastic bag waste management in African countries. Journal of Environmental and Public Health, 2020 (8892773), 1-8. doi: https://doi.org/10.1155/2020/8892773

(9) Rochman, C. M., Kross, S. M., Amstrong, J. B., Bogan, M. T., Darling, E. S., Green, S. J., Smyth, A. R., Verissimo, D. (2015). Scientific evidence supports a ban on microbead. Enviromment Sciences Technologi, 49(18), 10759-10761. doi: https://doi.org/10.1021/acs.est.5b03909

(10) Sucipto, C. D. S. (2012). Teknologi Pengolahan Daur Ulang Sampah. Yogyakarta: Gosyen publising

(11) Wijaya, B. S., Agustini, P. M., Hanathasia, M., Putri, D. M., dan Sutawidjaya, A. H. (2020). Why do people ignore the 'plastic bag diet' campaign? an Indonesian consumers perspective. IOP Conference Series: Earth Environment Sciences, 423(012009). https://iopscience.iop.org/article/10.1088/17551315/423/1/012009\#: :text=The\%20results\%20show\%20that\%20both,also\%20conside red\%20it\%20old\%2Dfashioned.

(12) Yorenza, Y., \& Yusran, R. (2020). Policy Implementation of the Use of Plastic Bags by Community and Business Players in Achieving Sdgs in Padang City. Science and Environmental Journal for Postgraduate, 3(1), 14-20. doi: https://doi.org/10.24036/senjop.v3i1.89

(13) Zhu, Q. (2011). An appraisal and analysis of the law of "Plastic-Bag Ban". Energy Procedia, 5, 2516-2521. doi: https://doi.org/10.1016/j.egypro.2011.03.432

(14) Yustiani, S. dan Maryadi (2019). Studi komparasi penerapan kebijakan penggunaan kantung plastik. Jurnal Pajak Indonesia, 3(2), 51-59. Diambil dari http://jurnal.pknstan.ac.id/index.php/JPl/article/view/717

(15) Adam, I., Walker, T. R., Bezerra, J. C., dan Clayton, A. (2020). Policies to reduce single-use plastic marine pollution in West Africa. Marine Policy, 116(6), 103928. doi: https://doi.org/10.1016/i.marpol.2020.103928

(16) Li, Z. dan Zhao, F. (2017). An analytical hierarchy process-based study on the factors affecting legislation on plastic bags in the USA. Waste Management \& Research: The Journal for a Sustainable Circular Economy, 35(8), 795-809. doi:

https://doi.org/10.1177/0734242x17705725 